\title{
Formalin Removal from Archival Tissue by Critical Point Drying
}

BioTechniques 33:604-611 (September 2002)

\author{
Sheng-Guo Fang1,2, Qiu-Hong \\ Wan $^{1,2}$, and Noboru Fujihara ${ }^{3}$ \\ ${ }^{1}$ Ministry of Education \\ Hangzhou, and ${ }^{2}$ Zhejiang Uni- \\ versity, Hangzhou, Zhejiang, \\ P.R. China, and ${ }^{3}$ Kyushu Uni- \\ versity, Hakozaki, Fukuoka, \\ Japan
}

\section{INTRODUCTION}

The analysis of DNA from fixed tissues allows investigators to study patients retrospectively for genetic changes (9). On the other hand, zoologists, evolutionary biologists, museum curators, and scientists interested in biological diversity require fixation methods that will preserve specimens for future study (6). Many studies have been conducted to determine the effects of various fixatives on the preservation and extraction of nucleic acids from fixed tissues. Ben-Ezra et al. (2) pointed out that ethanol fixation gave the best DNA results for PCR, while formalin produced poor results. The main reason is that formalin induces extensive crosslinking between nucleic acids and protein, while ethanol does not cause such extensive cross-linking and therefore adequately preserves the nucleic acids (2). However, in situ hybridization studies revealed that the detection of DNA using oligonucleotide probes was most successful in formalin-fixed tissue $(20,21)$, which suggests that nucleic acids are not destroyed by formalin but rather are made difficult to extract (19).

Previous methodologies reveal that only brief $(<24 \mathrm{~h})$ formalin fixation yields relatively unfragmented DNA and that fragmentation of extracted DNA is clearly evident with increasing fixation time $(5,16)$. In fact, to date, old fixed tissues did produce fragmented DNA $(<1.2 \mathrm{~kb})$ that could only be used for PCR amplification (12). The reasons why short-term fixation can produce high molecular weight DNA, while long-term fixation or old fixed specimens only produce smaller DNA fragments, may be related to the process of formalin fixation. Formalin fixation is referred to as a "clock reaction" because it is slow and requires $24-48 \mathrm{~h}$ to be completed (1). It follows that tissue exposed to formaldehyde for less than 24 $\mathrm{h}$ may be incompletely fixed, so comparatively intact DNA can be extracted. On the other hand, the most important feature of formaldehyde fixation is its ability to cross-link histone proteins and DNA, which is likely to affect the progression of proteinase K, Taq DNA polymerase, and restriction endonuclease, making DNA extraction, PCR amplification, and endonuclease digestion unsuccessful $(8,14)$. Although the cross-linking of histone proteins can be partly overridden by using proteolytic steps (14), the fixation-induced crosslinking of DNA that hampers hybridization cannot be dissociated by protease digestion. Thus, removing formalin and formaldehyde-induced cross-linking of proteins and DNA is most critical to DNA extraction.

The fact that the formation process of cross-linking between proteins and DNA is reversible in aqueous solutions (3) suggested to us that DNA could be recovered from formalin-fixed tissue. Here we report on high molecular weight DNA extraction from formalinfixed tissues (16-70 years old) by gradual dehydration of tissues, combined with the critical point drying method.

\section{MATERIALS AND METHODS}

Various formalin-fixed vertebrate tissues, including paraffin-embedded human postmortem tissue, were acquired from various sources (Table 1). The samples had been fixed in an 
Table 1. Date of Fixation, Species, Class, and Source of Formalin-Fixed Tissues

\begin{tabular}{|c|c|c|c|c|}
\hline Class & Species & Gender & Date & Tissue \\
\hline Fish & Acipenser sinensis & Male & $05 / 21 / 1951$ & aLiver \\
\hline Amphibia & Rana chensinensis & Female & $07 / 12 / 1943$ & bMuscle \\
\hline Reptilia & Ophiophagus hannah & Male & 07/11/1949 & bMuscle \\
\hline Aves & P. major & Female & 07/16/1984 & CLiver \\
\hline \multirow[t]{4}{*}{ Mammalia } & R. rattus & Female & 04/19/1930 & dLiver \\
\hline & Ailuropoda melanoleuca & Male & $11 / 03 / 1986$ & eLiver \\
\hline & Human & Female & 09/23/1958 & fKidney \\
\hline & Human (paraffin-embedded) & Male & 12/31/1966 & gLiver \\
\hline \multicolumn{5}{|c|}{ aFishes Specimen Museum of Southwest Agriculture University of China. } \\
\hline \multicolumn{5}{|c|}{ cTibet Biological Institute of China. } \\
\hline \multicolumn{5}{|c|}{ dMuseum of Sichuan University of China. } \\
\hline \multicolumn{5}{|c|}{ eChengdu Research Base for Giant Panda Breeding of China. } \\
\hline \multicolumn{5}{|c|}{$\begin{array}{l}\text { fInstitute of Tribunal Science and Technology of Chengdu Intermediate People's } \\
\text { Court, China. }\end{array}$} \\
\hline
\end{tabular}

excess volume of $10 \%(\mathrm{v} / \mathrm{v})$ formalin (unbuffered solution of formaldehyde, one part commercial reagent, and nine parts water) for periods ranging from 16 to 70 years. Rat (Rattus rattus) tissue was chosen to explore the optimization of DNA extraction from archival formalin-fixed specimens. In each test, $0.5 \mathrm{~g}$ rat liver underwent different dehydration processes for DNA isolation (Table 2 and Figure 1).

In addition, some fresh tissues were obtained from various vertebrates, including Ctenopharyngodon idellus (fish), Tigrina rugulosa (amphibian), Python molurus (reptile), Parus montanus saturatus (bird), and $R$. rattus (mammal). These were used as controls to compare the size of DNA obtained from the fixed samples to that from fresh samples in same taxonomic class. To identify the quality and quantity of DNA yields from fixed samples by DNA fingerprinting, fixed and frozen samples of human tissues were also acquired from the Institute of Tribunal Science and Technology of Chengdu Intermediate People's Court from the Chengdu People's Hospital of P.R. China.

\section{Isolation of DNA}

Each sample of fixed tissue $(0.5 \mathrm{~g})$ was divided into smaller portions (if the sample was paraffin-embedded, then we first used $5 \mathrm{~mL}$ xylene to deparaffinize). To avoid cell distortion, which can result from direct use of $100 \%$ ethanol to dehydrate tissue, gradual dehydration was performed on the tissues. This process may possibly prevent DNA fragmentation caused by sudden dehydration (23). The tissues were initially soaked in $30 \%$ ethanol for $20 \mathrm{~min}$ and then centrifuged at $3000 \times g$ for 10 min. Sediments were then soaked in $40 \%$ ethanol for $20 \mathrm{~min}$, and the centrifugation and sediment collection were repeated with increasingly stronger ethanol (10\% graded series) until dehydration in $100 \%$ ethanol.

After the final dehydration, the sediments were transferred to isoamyl acetate and soaked overnight. The sediments were collected by centrifugation at $3000 \times g$ and folded in a piece of filter paper. The filter paper containing the fixed tissue sediments was then placed in a small sample room of a critical point drying device (HCP-2 Critical Point Dryer; Hitachi, Tokyo, Japan), and liquid carbon dioxide was added to the sample room until the paper was completely immersed. For critical point drying, the sample room was maintained at $31^{\circ} \mathrm{C}$ for $2 \mathrm{~h}$, after which time the formaldehyde and ethanol were removed by opening the gas release valve.

After the gradual dehydration and critical point drying, the fixed tissues underwent the same extraction steps as fresh samples, according to the subsequent detection method. To do pulsedfield gel electrophoresis, the extraction of high molecular weight DNA from the fixed and fresh samples of same taxonomic class was done by a previously described dialysis method (17). The DNA from fresh and fixed samples used for PCR amplification and DNA fingerprinting was extracted by conventional phenol:chloroform methods (17).

\section{PCR Amplification}

Universal primers for 403- and 1198-bp fragments of the $c y t b$ gene, a part of mtDNA, were used for PCR amplification $(10,11)$. Another pair of primers for a 1844-bp fragment of Tcell receptor gene (nDNA) was also designed (22). All reactions $(50 \mu \mathrm{L})$ were performed using a PCR mixture containing $10 \mathrm{mM}$ Tris- $\mathrm{HCl}, \mathrm{pH} 8.4,50$ $\mathrm{mM} \mathrm{KCl,} 3 \mathrm{mM} \mathrm{MgCl} 2,250 \mu \mathrm{M}$ each dNTP, 100 pmol each primer, and $2 \mathrm{U}$ Taq DNA polymerase (Promega, Madison, WI, USA) at $94^{\circ} \mathrm{C}$ for $10 \mathrm{~min}$, $94^{\circ} \mathrm{C}$ for $1 \mathrm{~min}, 42^{\circ} \mathrm{C}$ for $1 \mathrm{~min}\left(54^{\circ} \mathrm{C}\right.$ for $1 \mathrm{~min}$ for $\mathrm{T}$-cell receptor gene), and 40 cycles of $72^{\circ} \mathrm{C}$ for $1 \mathrm{~min}, 72^{\circ} \mathrm{C}$ for $10 \mathrm{~min}$, and $4^{\circ} \mathrm{C}$ for $60 \mathrm{~min}$.

\section{Silver Mirror Test}

To see whether formalin was completely removed, it is necessary to perform a silver mirror test. The formalinfixed rat liver samples $(0.2 \mathrm{~g})$ were ground to a fine powder that was transferred to a tube and soaked in $1 \mathrm{~mL}$ water for $24 \mathrm{~h}$. As negative controls, $0.2 \mathrm{~g}$ each of the differently processed liver materials (i.e., only dehydrated by $30 \%-100 \%$ series ethanol and processed by gradual dehydration and critical point drying) were treated in the same manner. The silver mirror test was performed as previously described (7).

\section{Pulsed-Field Gel Electrophoresis}

Pulsed-field gel electrophoresis was performed according to the instruction manual and application guide of the instrument (CHEF-DR III; Bio-Rad Laboratories, Hercules, CA, USA). DNA size markers and high molecular weight DNA were loaded onto $1 \%$ 
Table 2. DNA Extractions and Amplifications from Fixed, Dehydrated, Completely Processed, and Fresh Mouse Liver

\begin{tabular}{|c|c|c|c|c|c|c|c|c|c|c|c|c|c|c|c|c|}
\hline \multirow{3}{*}{$\begin{array}{l}\text { Liver } \\
(0.5 \mathrm{~g})\end{array}$} & \multicolumn{10}{|c|}{ Processing } & \multicolumn{3}{|c|}{$\begin{array}{l}\text { DNA Data } \\
\left(\mu g^{a}, k^{b}\right)\end{array}$} & \multicolumn{3}{|c|}{$\begin{array}{c}\text { PCR } \\
\text { Amplification (bp) }\end{array}$} \\
\hline & \multicolumn{8}{|c|}{ Graded Ethanol for Dehydration (\%) } & \multirow[b]{2}{*}{ C } & \multirow[b]{2}{*}{$\mathbf{P}$} & \multirow{2}{*}{$\begin{array}{l}\text { DNA } \\
\text { Yield }\end{array}$} & \multirow{2}{*}{$\begin{array}{c}\text { A } \\
\text { Ratio }\end{array}$} & \multirow{2}{*}{$\begin{array}{l}\text { DNA } \\
\text { Size }\end{array}$} & \multicolumn{2}{|c|}{ mtDNA } & \multirow{2}{*}{$\frac{\text { nDNA }}{1844}$} \\
\hline & 30 & 40 & 50 & 60 & 70 & 80 & 90 & 100 & & & & & & 403 & 1198 & \\
\hline \multirow[t]{5}{*}{ Fixed } & - & - & - & - & - & - & - & - & - & + & 27.8 & 1.33 & 0.10 & - & - & - \\
\hline & - & - & - & - & - & - & + & + & - & + & 37.9 & 1.40 & 0.25 & - & - & - \\
\hline & - & - & - & - & + & + & + & + & - & + & 35.4 & 1.47 & 1.00 & + & - & - \\
\hline & - & - & + & + & + & + & + & + & - & + & 42.3 & 1.73 & 2.00 & + & - & - \\
\hline & + & + & + & + & + & + & + & + & - & + & 72.6 & 1.67 & 2.00 & + & - & - \\
\hline
\end{tabular}

pulsed-field certified agarose, and electrophoresis was performed in $0.5 \times \mathrm{TBE}$ (45 mM Tris, $\mathrm{pH} 8.3,45 \mathrm{mM}$ borate, 1 $\mathrm{mM}$ EDTA) for $22 \mathrm{~h}$ at $6 \mathrm{~V} / \mathrm{cm}$ and $14^{\circ} \mathrm{C}$. The pulse angle was $120^{\circ}$, and the switch time was 50-90 s.

\section{DNA Fingerprinting}

All methods for DNA fingerprinting were carried out as described by Nanda et al. (13) and Schäer et al. (18). The probe, 5'-AGAGGTGGGCAGGAGAGGTGGGCAGGT-3', was prepared as described by Fang et al. (4).

\section{RESULTS AND DISCUSSION}

The size of the isolated DNA varied greatly among different processing methods (Figure 1). Using 30\%-100\% ethanol to dehydrate fixed tissue produced large $(>2 \mathrm{~kb})$ DNA fragments (Figure 1a, lane 6), but processing by gradual dehydration and critical point drying (Figure 1a, lane 7) resulted in the extraction of high molecular weight DNA (approximately $20 \mathrm{~kb}$ ) that was identical to the size of the genomic DNA from fresh liver (Figure 1a, lane 8). The fresh tissues and those processed by critical point drying resulted in high DNA yields and the highest absorbance $(260 / 280 \mathrm{~nm})$ ratios (Table 2$)$.
Although gradual dehydration is helpful for DNA extraction, it alone cannot give high molecular weight DNA.

Why can critical point drying lead to the extraction of high molecular weight DNA? The rationale of critical point drying lies in the use of temperature and pressure, both of which are higher than critical temperature and critical pressure, being used to evaporate fluid (in this case formalin) in tissues and dry them completely. The silver mirror test indicated that formalin had been removed completely only from those tissues processed by gradual dehydration and critical point drying (Figure 2). Samples dehydrated in a graded series of ethanol still showed traces of formalin. This indicates that critical point drying resulted in the complete removal of formalin and fixation-induced crosslinking, thus allowing high molecular weight DNA to be extracted from the fixed samples.

A short fragment (an approximately 403-bp cytb gene), used to test if PCRs could be reliably performed, was amplified from gradual dehydration (70\%$100 \%$; 50\%-100\%; and 30\%-100\%) from tissue processed by critical point drying and from fresh liver (Figure 1). A 1198-bp cytb gene and a 1844-bp T-cell receptor gene, used to verify if longer fragments of different sources could be also amplified, were only isolated from

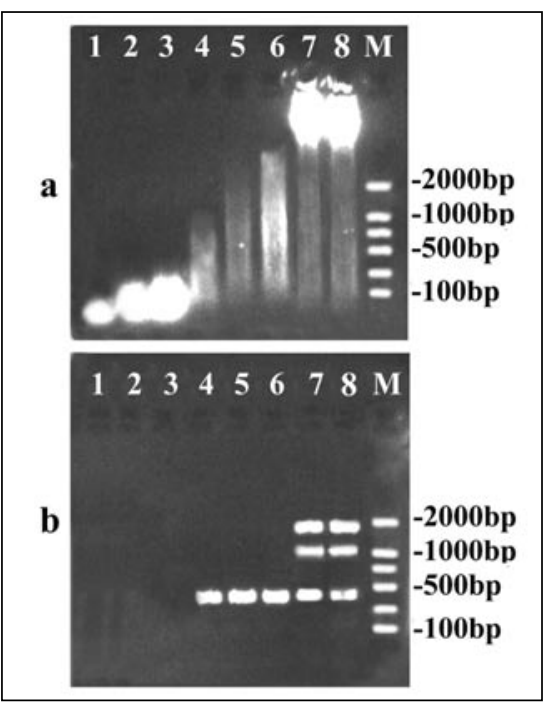

Figure 1. Amplification comparison among DNA extracted from fixed tissues, tissues processed by graded dehydration, and tissues processed by critical point drying. (a) Extracted DNA from fixed (lane 1) and fresh (lane 8) mouse liver and formalin-fixed liver ( $R$. rattus) processed by a $10 \%$ graded series of ethanol dehydration (lanes 2-6) or processed by critical point drying (lane 7). Lane 1, fixed; lane 2, $100 \%$ ethanol only; lane $3,90 \%$ and $100 \%$; lane $4,70 \%-100 \%$; lane 5, 50\%-100\%; lane 6, 30\%-100\%; lane 7, $30 \%-100 \%$ ethanol and critical point drying; lane 8 , fresh liver; and M, size marker (DL-2000 marker; Takara Biotechnology, Dalian, P.R. China). (b) PCR amplification for 403-bp and 1198-bp fragments of the $c y t b$ gene and a 1844-bp fragment of T-cell receptor gene using genomic DNA from Figure 1a, lanes 1-8, as template DNA (each PCR was carried out alone, but the mixture of three PCR products was loaded onto the gel). 
completely processed liver and fresh samples (Figure 1), even though the gradual dehydration $(70 \%-100 \%$ and $50 \%-100 \%$ ) produced DNA fragments larger than $2 \mathrm{~kb}$. Because gradual dehydration is unable to replace formaldehyde completely, remnant cross-linking between histone proteins and DNA may hamper the progression of Taq DNA polymerase, causing amplification failures of the longer fragments.

Combined with gradual dehydration and critical point drying, dialysis produced DNA larger than $194 \mathrm{~kb}$ from fresh, fixed, and paraffin-embedded tissues (Figure 3), even though the samples were from different classes of ver-

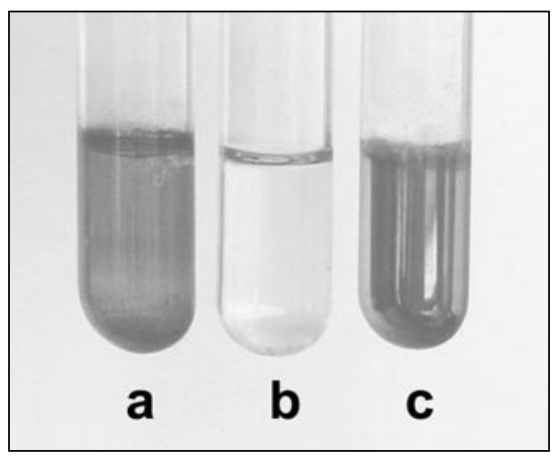

Figure 2. Silver mirror test on different tissues. Tube a contains samples only dehydrated in the 30\%-100\% series of ethanol; tube b contains materials processed by graded dehydration and critical point drying; and tube c contains fixed tissues (i.e., no removal of formalin).

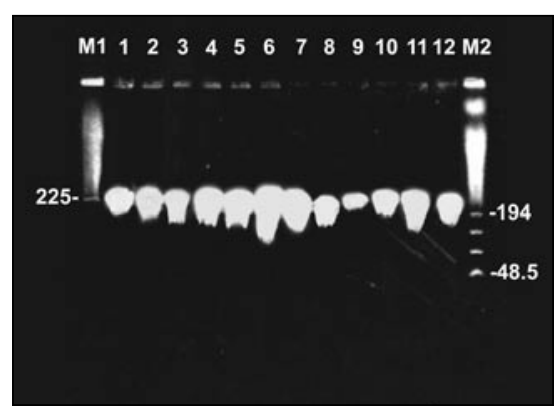

Figure 3. Pulsed-field gel electrophoresis of DNA extracted by dialysis. M1, yeast DNA pulsed-field gel electrophoresis markers; lane 1, A. sinensis (fixed tissue); lane 2, C. idellus (fresh tissue); lane $3, R$. chensinensis (fixed tissue); lane 4, T. rugulosa (fresh tissue); lane 5, O. hannah (fixed tissue); lane 6, P. molurus (fresh tissue); lane 7, P. major (fixed tissue); lane 8, P. montanus saturatus (fresh tissue); lane $9, R$. rattus (fixed tissue); lane 10, R. rattus (fresh tissue); lanes 11 and 12 , human (fixed tissue and fixed and paraffinembedded tissue, respectively); and M2, $\lambda$ DNA pulsed-field gel electrophoresis markers. tebrate and had been fixed in formalin for different periods of time. According to the literature (15), the fixation-induced cross-linking of DNA appears to hamper hybridization. However, when the banding patterns of old fixed tissues and fresh samples were compared by DNA fingerprinting (Figure 4), the DNA banding patterns showed that the DNA fingerprints of formalin-fixed in- dividuals presented the same number of bands as the fingerprints of frozen individuals (i.e., the fixed DNA was completely digested by restriction endonuclease and actually hybridized with the probe). This suggests that the quantity and quality of DNA from fixed tissues are reliable. DNA extracted from old fixed samples after the dehydration process and critical point drying is 


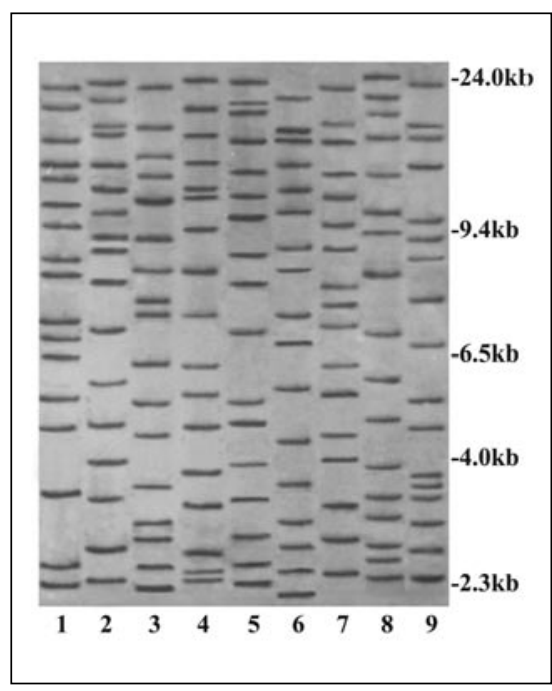

Figure 4. Fingerprinting analysis of five formalin-fixed human specimens (lanes 1, 3, 5, 7, and 9) and four frozen human muscles (lanes $\mathbf{2 , 4 , 6}$, and 8). Lane 1, kidney; lane 3 , liver; lane 5 , ovary; lane 7 , liver; and lane 9, muscle.

identical to that from fresh tissues (Figures 1,3 , and 4) and is reliably applied to PCR and fingerprinting. The findings indicate that old formalin-fixed tissue samples can now be effectively applied to molecular genetic studies, phylogenetic relationship analysis, forensic DNA detection, and retrospective clinicogenetic analysis.

\section{ACKNOWLEDGMENTS}

We thank the organizations that provided samples (see Table 1). We give special thanks to Dr. Charlie Manolis for his helpful amendments and comments on the manuscript. The work was supported by a grant no. G2000046906 from the State Key Basic Research and Development Plan of P.R. China.

\section{REFERENCES}

1.Battifora, H. 1991. Effect of fixatives and fixation times on the tissues. Am. J. Clin. Pathol. 96:144-145.

2.Ben-Ezra, J., D.A. Johnson, J. Rossi, N. Cook, and A. Wu. 1991. Effect of fixation on the amplification of nucleic acids from paraffin-embedded material by the polymerase chain reaction. J. Histochem. Cytochem. 39:351-354.

3.Dubeau, L., L.A. Chandler, J.R. Gralow, P.W. Nichols, and P.A. Jones. 1986. Southern blot analysis of DNA extracted from formalinfixed pathology specimens. Cancer Res.
46:2964-2969.

4.Fang, S.G., M. Huang, G.Q. Chen, Z.W. Ding, and L. Lan. 1997. The preparation of fish oligonucleotide fingerprinting probe. Acta Genetica Sinica 24:7-14.

5.Forsthoefel, K.F., A.C. Papp, P.J. Snyder, and T.M. Prior. 1992. Optimization of DNA extraction from formalin-fixed tissue and its clinical application I Duchenne muscular dystrophy. Am. J. Clin. Pathol. 98:98-104.

6.Greer, C.E., S.L. Peterson, N.B. Kiviat, and M.M. Manos. 1991. PCR amplification from paraffin-embedded tissues. Effects of fixative and fixation time. Am. J. Clin. Pathol. 95:117123.

7.Gu, M.M. 1991. The Experiments of Organic Chemistry. Fudan University Press, Shanghai, P.R. China.

8.Hamazaki, S., M. Koshiba, T. Habuchi, R. Takahashi, and T. Sugiyama. 1993. The effect of formalin fixation on restriction endonuclease digestion of DNA and PCR amplification. Pathol. Res. Pract. 189:553-557.

9.Heller, M.J., L.J. Burgart, C.J. TenEyck, M.E. Anderson, T.C. Greiner, and R.A. Robinson. 1991. An efficient method for the extraction of DNA from formalin-fixed, paraffin-embedded tissue by sonication. BioTechniques 11:372-377.

10.Irwin, D.M., T.D. Koucher, and A.C. Wilson. 1991. Evolution of the cytochrome b gene of mammals. J. Mol. Evol. 32:128-144.

11.Koucher, T.D., W.K. Thomas, A. Meyer, S.V. Edwards, F.X. Villavlance, and A.C. Wilson. 1989. Dynamics of mitochondrial DNA evolution in animals: amplification and sequencing with conserved primers. Proc. Acad. Sci. USA 86:6190-6200.

12.Liu, J., R.M. Johnson, and S.T. Traweek. 1993. Rearrangement of the BCL-2 gene in follicular lymphoma. Detection by PCR in both fresh and fixed tissue samples. Diagn. Mol. Pathol. 2:241-247.

13.Nanda, I., W. Feichtinger, M. Schmid, J.H. Schröder, H. Zischler, and J.T. Epplen. 1990. Simple repetitive sequences are associated with differentiation of the sex chromosomes in the Guppy fish. J. Mol. Evol. 30:456462.

14.O'Leary, J.J., G. Browne, R.J. Landers, M. Crowley, I.B. Healy, J.T. Street, A.M. Pollock, J. Murphy, et al. 1994. The importance of fixation procedures on DNA template and its suitability for solution-phase polymerase chain reaction and PCR in situ hydridization. Histochem. J. 26:337-346.

15.Pavelic, J., K. Gall-Troselj, M.H. Bosnar, M.M. Kardum, and K. Pavelic. 1996. PCR amplification of DNA archival specimens. A methodological approach. Neoplasma 43:7581.

16.Sato, Y., R. Sugie, B. Tsuchiya, T. Kameya, M. Natori, and K. Mukai. 2001. Comparison of the DNA extraction methods for polymerase chain reaction amplification from formalin-fixed and paraffin-embedded tissues. Diagn. Mol. Pathol. 10:265-271.

17.Sambrook, J., E.F. Fritsch, and T. Maniatis. 1989. Molecular Cloning: A Laboratory Manual. CSH Laboratory Press, Cold Spring Harbor, NY.

18.Schäer, R., H. Zischler, U. Birsner, A. Bech- er, and J.T. Epplen. 1988. Optimized oligonucleotide probe for DNA fingerprinting. Electrophoresis 9:369-374.

19.Simel, E.J., L.R. Saidak, and G.A. Tuskan. 1997. Enhanced DNA extraction and PCR amplification of mitochondrial genes from formalin-fixed museum specimens. BioTechniques 22:394-400.

20.Tyrrell, L., J. Elias, and J. Longley. 1995. Detection of specific mRNAs in routinely processed dermatopathology specimens. Am. J. Dermatopathol. 17:476-483.

21.Weiss, L.M. and Y.Y. Chen. 1991. Effects of different fixatives on detection of nucleic acids from paraffin-embedded tissues by in situ hybridization using oligonucleotide probes. J. Histochem. Cytochem. 39:12731242 .

22.Williams, C.B., E.P. Blankenhorn, K.E. Byrd, G. Levison, and G.A. Gutman. 1991. Organization and nucleotide sequence of the rat $\mathrm{T}$ cell receptor $\beta$-chain complex. J. Immunol. 146:4406-4413.

23.Zhu, L.X., R.Q. Cheng, and X.Z. Gao. 1982. Techniques of Electron Microscope in Biology. Peking University Press, Beijing, P.R. China.

Received 10 January 2002; accepted 22 May 2002.

Address correspondence to:

Dr. Sheng-Guo Fang

Department of Biology

College of Life Sciences

Zhejiang University

Kai Xuan Road No. 268

Hangzhou 310029, Zhejiang, P.R. China

e-mail:sgfang@mail.hz.zj.cn

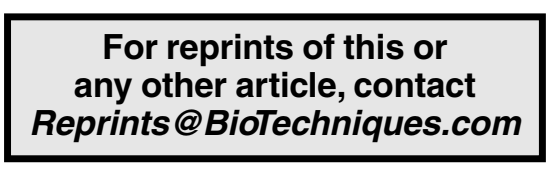

